\title{
Invisible Housing-"housing" as envisioned by the urban poor in Jakarta
}

\author{
Mukti Andriyanto ${ }^{1, *}$, Triatno Yudo Harjoko ${ }^{1}$ \\ ${ }^{1}$ Department of Architecture, Faculty of Engineering, Universitas Indonesia, Indonesia
}

\begin{abstract}
This paper seeks to challenge the dominant paradigm on housing only as an standarized object for living. For the urban poor, urbanity is conceived as petromax that attracts them to come to the city striving for fortune. What really matters is how they could get access to space or "a piece of land" (lahan) in the city,which may not mean it housing let alone home. A house is imagined as a shelter that lets them engage with economic activities within. It does not have all the basic facilities needed to raise a healthy family as understood and believed by politicians, bureaucrats and those in the property business. The research method used in this projects in order to discover the metaphysical phenomena of invisible housing is a grounded method. The idea of invisible housing is uncovered through an emic approach of investigations to the respondents. Findings have shown that the urban poor perceive urbanity as space of existence. Open lahan or open urban land (such as on river bank) perceived as "no man's land" for them to utilize.
\end{abstract}

\section{Introduction}

About $68 \%$ of Indonesians build their own houses, while the other $15 \%$ buy new houses from formal markets (Esariti \& Nirwanto, 2008). The need for housing for low-income households has become a government's concern since the establishment Perumnas, a state-owned house developer, in 1974 (Raharjo, 2010).But in reality, low-income workers who are working in the informal economy sector prefer to buy houses in the informal market rather than the formal one. This phenomenon occurs due to people's low purchasing power (Pembiayaan Perumahan, 2016)or the limited access to the housing finance system(Mangeswuri, 2016, pp. 8395).

A statement from John F.C. Turner, in "Freedom to Build" published in 1972, is still relevant to see the failurehousing absorption in the formalmarket for lowincome people(Turner, 1972). The government is considered incapable to distinguish the material role [as what it is] or what housing can do to people's lives(Turner, 1972). Arifin(2007)stated that in Indonesia, the challenge of "housing needs" is always about the number of houses to be built and the types of houses that people want. The housing development never really addresses the other important element, and that is the people's real aspirations in the process of house-ing, in the term of Turner.

This study reveals the ussue of use values of a house, its role for the lives of low-income people in order to survive in urban areas. Invisiblehousing is defined as houses, that were not built based on basic technical standards, utilized by low-income residents who work in the informal sector. Turner (1977, p. xxxiv), mentioned "dweller satisfaction", he thought that the most important thing of a house is not its physical condition, or "what it is," but rather its metaphysical condition of "what it does to people's live". So dwelling does not depend on any certain physical standard(Turner, 1977).

\section{Method}

The aim of this research is to uncover the urban poor's definition of dwelling as well as housing in the city. The research has deployed a grounded theory which is used and formulated throughout the data collection. It focuses on what and how the poor perceive housing in their own understanding and then compare it to the dominant paradigm of the politicians, bureaucrats, and especially the developers. The diagram below (Figure 1 and Figure 2) shows how the author will discuss the differences between Visible and Invisible Houses and how the housing process occurs in the interaction between houses and human activities.

\footnotetext{
*Corresponding author: gotty@eng.ui.ac.id
} 


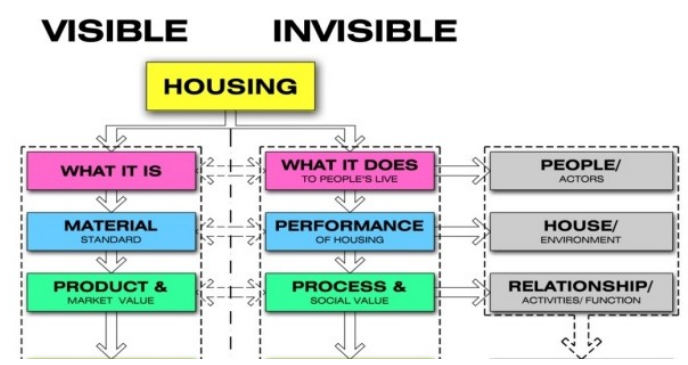

Fig 1. Schematic Diagram of Visible and Invisible Housing

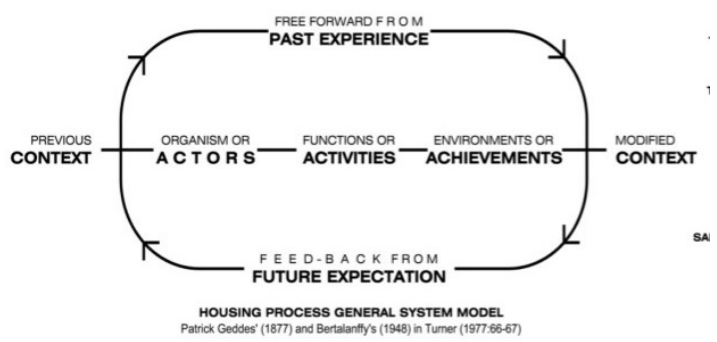

Fig 2. Housing Process System Model

\section{Result and Discussion}

\subsection{Pengadegan and Inherited Land}

The case study was located in the area of RW 01, the most populated in the Pengadegan sub-district, called Djaelani alley, or Gang Djaelani (Figure 3 and Figure 4). It is located about 350 meters to the North Sea from the office of local government of Pengadegan Sub-district (see Figure 2). The distance of Gang Djaelani to the banks of the Ciliwung River is only 60 meters away, causing it to be flooded during the rainy season, which usually occurs in February. Gang Djaelani is one of the several migrant areas in RW 01. The width of Gang is only around 2 meters (Figure 4 and Figure 5). Some native people of Betawi still live in the area and control their inherited lands and have them for lease. At Gang Djaelani, there are two migrant clusters where each cluster has houses that belong to the informal workers (Figure 4). In cluster 1 (Figure 6), there are tempe craftsmen, street tailors and pindang fish makers; meanwhile on cluster 2 (Figure 7), there are tempe craftsmen, tofu craftsmen, lontong makers, dairy farmers, vegetable traders. They choose to rent land on the riverbank from the people of Betawi, because it is cheap and they can freely build residential space and areas for their informal economic activities.

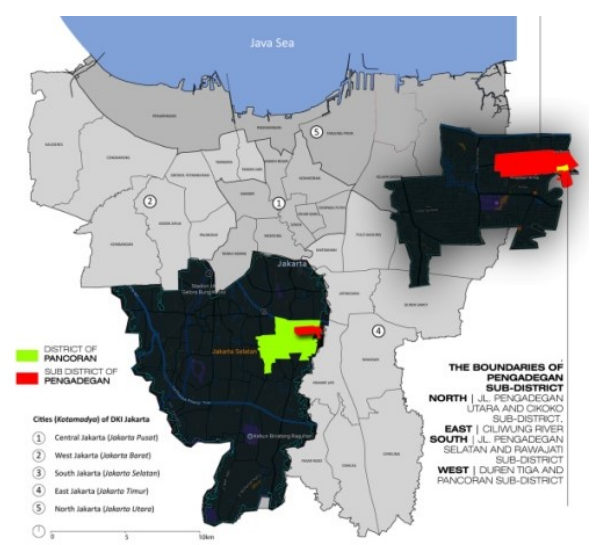

Fig 3. Area of District Pancoran(green).Sub District Pengadegan(red), and RW 01 (yellow) on part of Jakarta

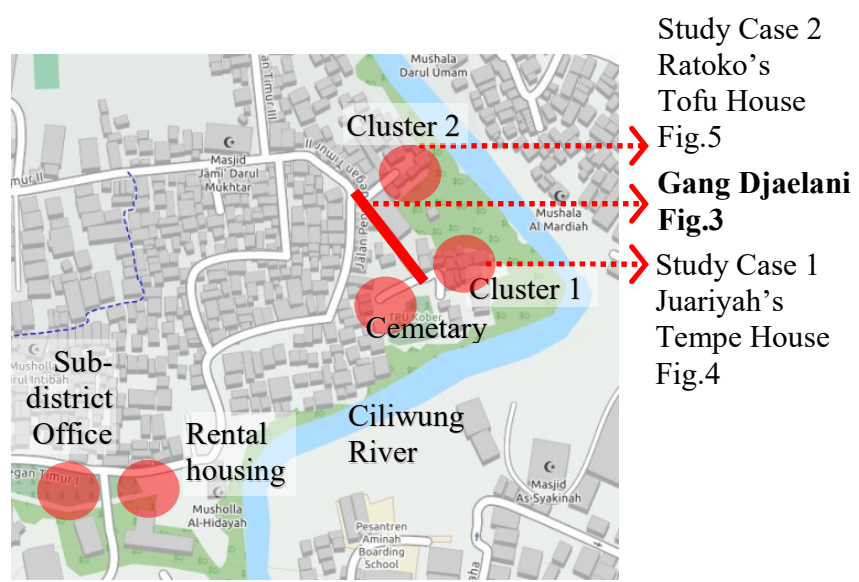

Fig 4. Gang Djaelaniand study case position

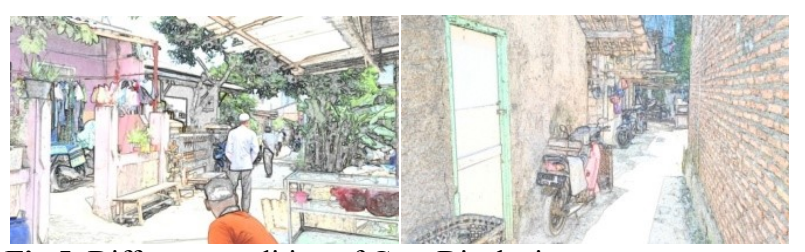

Fig 5. Different condition of GangDjaelani

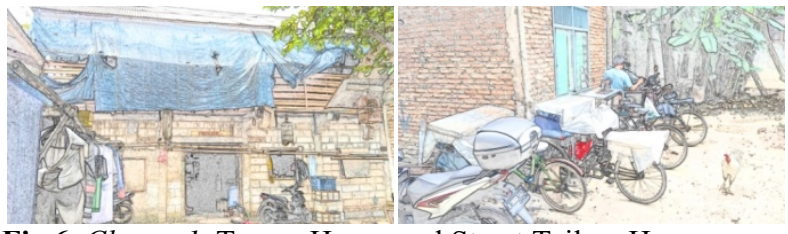

Fig 6. Cluster 1, Tempe House and Street Tailors House

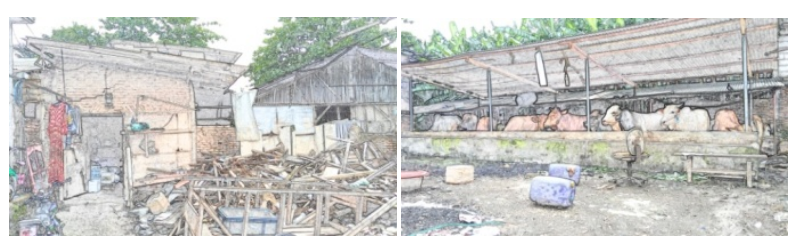

Fig 7. Cluster 2,Tofu House and Dairy Farmers Area

\subsection{Juariyah's House}

\subsubsection{Past and Current}

Juariyah, a migrant from Pekalongan, Central Java, her husband Ashraf, came to Jakarta in the 1990s. Like most 
migrant residents from Pekalongan in Jakarta who had that already in Jakarta, who had worked in the tempe and tofu business, Her husband decided to do the same in order to survive living in the capital. Their early tempe production was done in their house located in Cikoko area, located more than 2 kilometers from the current location at Gang Djaelani, Pengadegan Sub-district. The location used by Juariyah's husband for production house was close to the river. The decision for choosing the location was simply because the waste of the soybean processing could be easily poured into the river. Renting the land was considered easier and cheaper because they could do it for a longer period of time and it could be utilized to support their production even though the building was built with simple materials. Her husband lived for nearly 20 years in Cikoko subdistrict. While living in Cikoko, Asraf had to become a craftsman apprentice to a more senior craftsman before he was able to rent a large land which could accommodate some of the younger craftsmen. But since the landowner in Cikoko wanted to transform his land for another function, Juariyah's husband decided to move their house and production business to an area in the banks of Ciliwungriver.

In 2010, Juariyah's husband rented an empty 90square-meter piece of land belonging to Pak Abid, a native of Betawi who lives about 50 meters from site where Juariyah is making tempe, with a ten-year lease term up to 2021. Unfortunately, Juariyah moved to her new house without her husband. Her husband had passed away before they moved into the new house and the children decided to be left at their hometown. The house is only occupied by her and six craftsmen and workers. The rented land is only about 30 meters from the Ciliwung River. It is often flooded for days. Water from overflowing rivers often go to residential areas, reaching from 100 to 300 centimetres. In February 2017, for example, the floods from the overflowing Ciliwungriver, reached up to 200 centimeters.

\subsubsection{People and House}

The house, which is currently has the size of 90 to 120 square meters, consists of two floors. The ground floor is used for the production and where Juariyah live, while the upper floor is used for the residence of the craftsmen and workers. In total there are seven groups of workers who are involved in the tempe production, including Juariyah herself, who all come from Pekalongan. Each group consists of workers who live on the same floor. There are seven rented rooms and the six groups occupy the six rental rooms upstairs and they can take advantage of the production space alternately with the compensation to Juariyah of 3 litres of soybean per day.All the other workers live in the remaining room. Three out of six of these groups are couples with toddlers. The seven working groups took turns starting at 5 am and all work will last until afternoon at around 3 $\mathrm{pm}$. The relationships between Juariyah and the craftsmen can be illustrated in the diagram below (Fig.10). Inside Juariyah's house there are one main craftsperson (Juariyah) and six craftsmen with six workers, who help the craftsmen in the process of making tempe. The connection between them is shown in the Figure 10. Overall the economic relationships between needs and markets of tempe craftsmen and other parties can be seen in Figure 10. In the diagram it shows that although the tempe production location is in Pengadegan but it is quite far from the market. So the tempe craftsmen are basically some of city's economic drivers instead of its parasites.

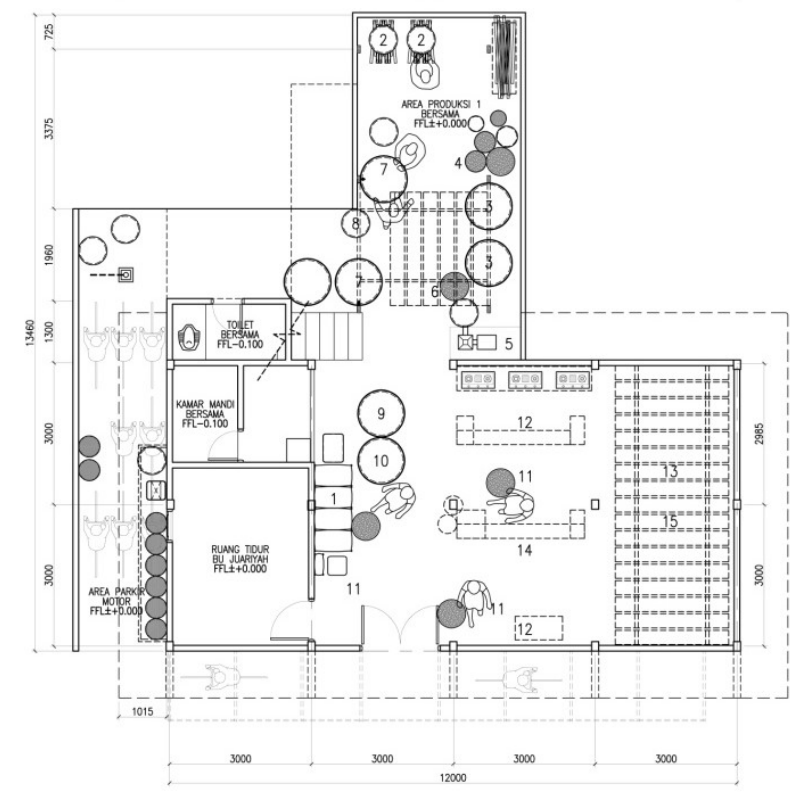

Fig 8. Ground Floor Plan of Juariyah House

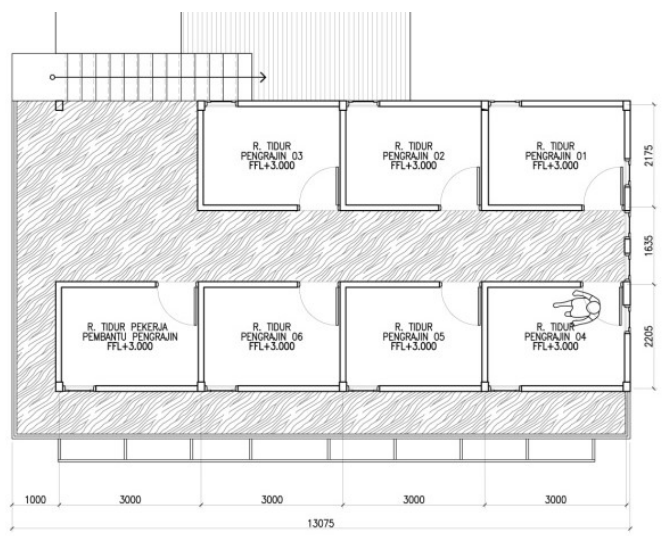

Fig 9. Upper Floor Plan of Juariyah House

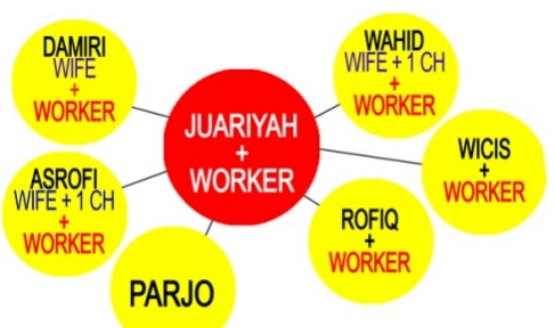




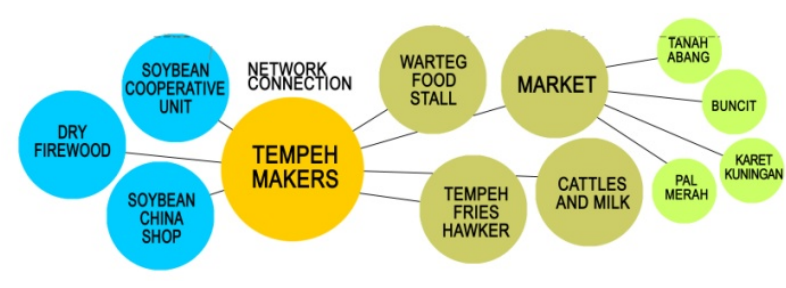

Fig 10. Intra-Connection and Inter-Connection Tempe Craftsmen Network

Some below Figure 11 are activities contained in Juariyah'shouse :

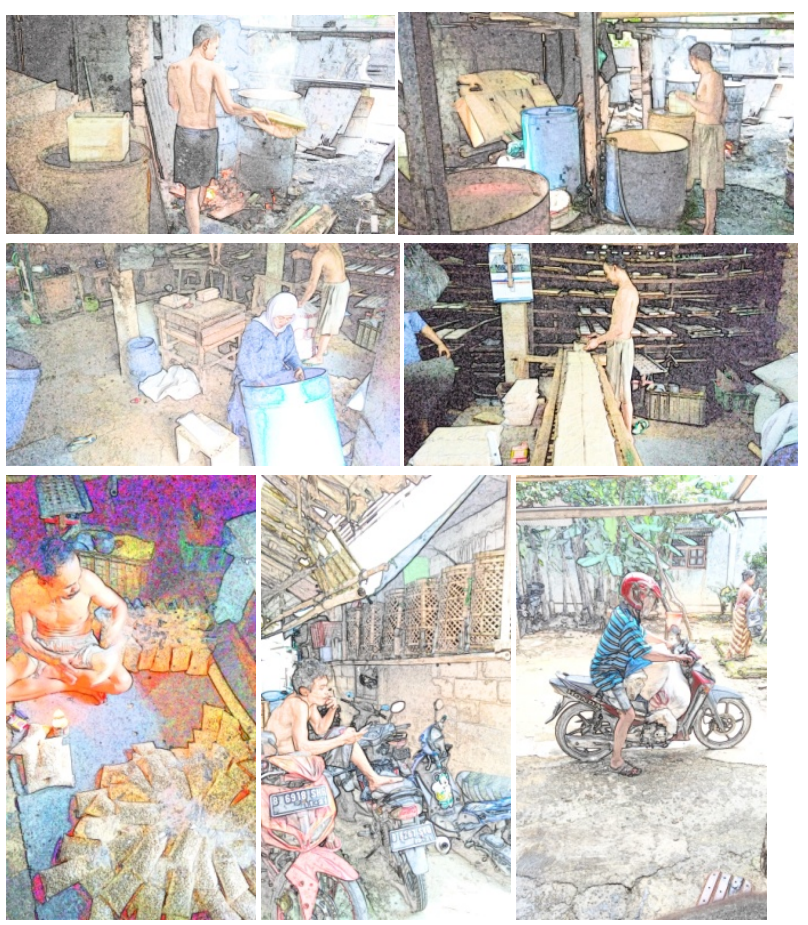

Fig 11. (1) Boiling soybean; (2) Seperating outer skin soybean; (3) Fermentating and drying; (4-5) Packaging in plastic over the "krey"; (6) the parking area of the motor that is used as a place to rest while waiting for the kitchen usage scheduleg; (7) Transporter of soybean pulp for cattle feed

\subsection{Ratoko's House}

\subsubsection{Past and Current}

Ratoko is also a migrant from Pekalongan. At first he came to Jakarta to follow one of his relatives to learn to make tofu. Later on he went to work with one of the big tofu business owners in Pengadegan, a man named Asep, a Sundanese. With the experience he had learned from working with others, he started his own tofu business in the 1990 s by renting a land on the bank of the Ciliwungriver. He rented a piece of 150-square meter land in Pengadegan. It turned out, Ratoko and the landowner were in a position that they could help each other out. As the landowners had a fresh milk business, for the lease, Ratoko had to give the dregs of tofu each day to be used as food for the cows. This mutualistic relationship lasted for long until the landowner passed away and his business was transferred to another family member. After that, Ratoko was required to pay the rent for $\mathrm{Rp} 8$ million each year. In the past his business employed eight workers who stayed in the same location in 2006 when the level of production was a lot more than now. Its soybean stock could reach up to 2.5 tons. This wasbefore the big flood in 2007 and the soybean price increases and the issue of the use of formalin in 2006 to 2009. After that his business just went downhill and nowhe only gets help from his wife and his brother Atmojo.

\subsubsection{People and House}

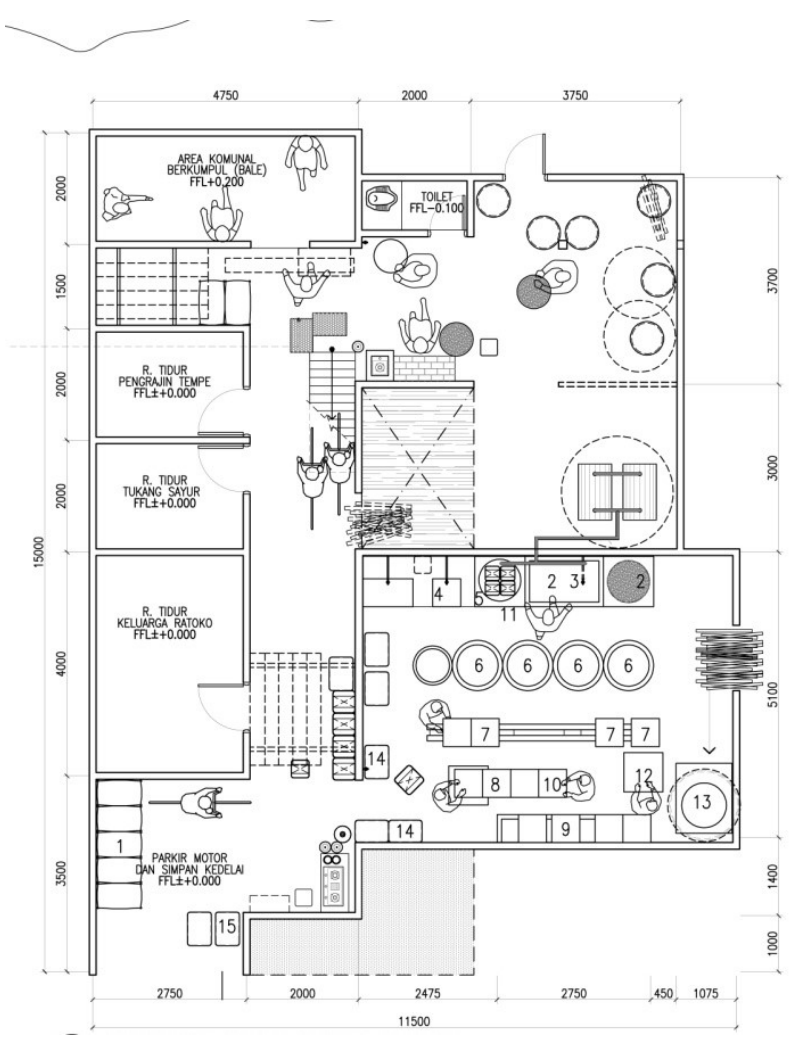

Fig 12. Ground Floor Plan of Ratoko's House

Ratoko lives with his wife and one of his sons who is 10 years old. His other two children live in Pekalongan. There are many activities done in Ratoko's house, including the tempe production, lontong cooking process and vegetable preparation for sale. Ratoko has two spare rooms that he rents to tempe a craftsman and vegetable sellers. The tempe craftsman is given a work space on the north side of the house while Ratoko takes up space on the south side. The northern side of the work is also rented by lontong traders who live not far from Ratoko's house (see Figure 12). There are a total of five rooms in Ratoko's house. While Ratoko lives with his wife and son on the ground floor, the vegetable trader and tempe craftsman live on the north side of Ratoko's room. Atmojo, a worker who helps Ratoko, lives in one of the two rooms available at upper floor. There are several similarities between Juariyah and Ratoko. They treat houses not based on the physical condition but most importantly is the location of the land where they can live and work. Their land is next to river appropriate to their production needs. Both also apply regularly a barter 
system with other people. Ratoko with the landowner and Juariyah with other tempe craftsmen.
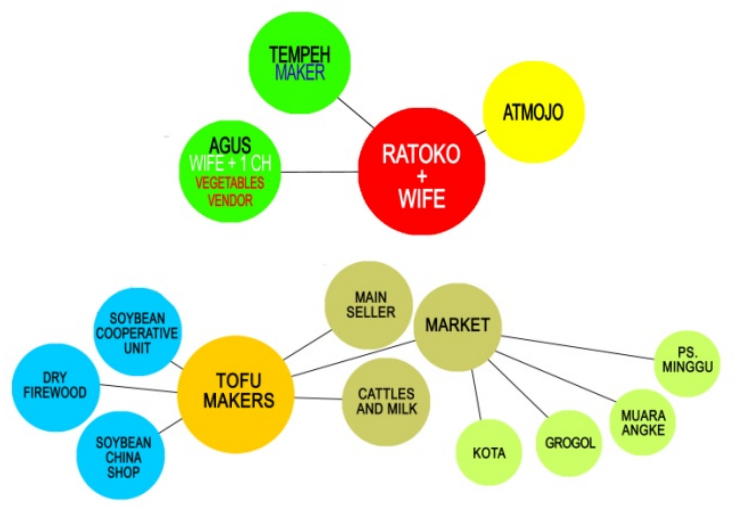

Fig 13. Intra-Connection and Inter-Connection Tofu Maker Network

Based on the above diagram (Figure13), even though Ratoko's house looks bigger than Juariyah's and its rental price is also more expensive but it turns out that the intra-connection inside Ratoko's house is not as complex as the one in Juariyah's house. The relationships with other business actors outside Ratoko's house are more or less similar to the ones done by those living in Juariyah's house. And although Ratoko only sells in PasarMinggu, which is located about 3 kilometers from the production site, but Ratoko has access to markets access. Some pictures below show the activities related to tofu production in Ratoko's house

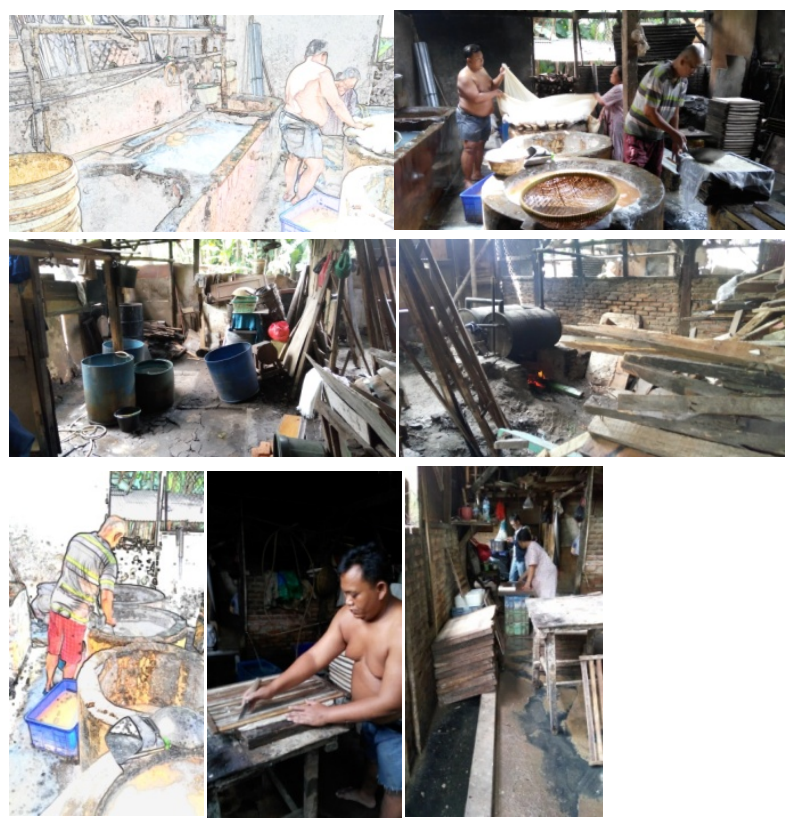

Fig 12. (1) Boiling process; (2) Soybean filtration process; (3) Area of tempe and lontong production; (4) Area of steam induction to boil tofu soybean; (5) The cooking process of tofu; (6) Tofumolding process; (7) Frying preparation process

\section{Discussion}

\subsection{Craftsman}

Tempe and Tofu craftsmen in Jakarta are migrant communities mostly originating from Pekalongan, Central Java. They migrated to Jakarta because of the desire to seek a better life by getting work in the city. Their decision to go to the capital was usually based on an invitation from friends or relatives who had already become tempe or tofu craftsmen. Since they all come from Pekalogan, these craftsmen have a strong cultural bond living in Jakarta. Every migrant from Pekalongan who is in the tempeor tofu business goes through the same experience. They will start their career working for someone who has encouraged them to come to Jakarta. It takes years before they can have their own business as they will have to learn about the production and to have a solid network of the business. Workers who become craftsmen and have experience are usually able to set aside some of their income to finally start their own business, either on their own land or rent one from someone. Others craftsmen have even started to get earn additional income from renting out bedrooms, work space or communal kitchens. Based on that, tempe or tofu craftsmen can be grouped into three categories namely (1) workers; (2) craftsman and (3) parties who have a communal kitchen or can be called the "boss" group of craftsmen.

\subsection{Invisible House}

As immigrants in Jakarta, the workers who help tempe craftsmen live in a place provided by the craftsmen, their employers. Since they don't need to pay for anything to stay, these workers will not protest about the condition of the houses. All they need is a place to sleep. Craftsmen, who are not able to rent a land or a production house, can rent a house from another craftsperson, like in the case of Juariyah. Another way is to rent a production area, like the case with Ratoko and his house. Some of the main important things when deciding to rent for a production area are that it must be affordable and is close to water channel or the river. The craftsmen can only produce cheap tempeand tofu if the rental cost is low.

One solution is to rent a land that is not utilized. A land like this can be found on the river banks, but risky with floods. This is what craftsmen from Pekalongan usually do, by not getting a house from the informal market but occupying a land with at an affordable rental fee. The cost for building a production area can be found from saving some money - as what Juariyah did - or through getting a loan from the loan sharks, something that Ratoko had no choice from doing. A cheap production house can be seen from the appearance of its physical condition, made of makeshift materials. Such a house does not look like any other common house. The finishing materials used are not the standardized materials used in normal houses made by any developer or government. Tempe and tofu craftsmen are not concerned with the physicalcondition of their houses, but to them the most important thing is that they have a shelter and also a production site. So the materials that make up the physical condition of normal houses are not 
something that these craftsmen's houses may speak of. Juariyah's house, for example, uses exposed concrete columns as the main structure, while the materials used on the walls are exposed wood and corrugated iron bricks. Its roof is made of corrugated zinc and the floor is made up from a hardened soil material. At Ratoko's house the materials used for building the house are much more below the quality of Juariyah's house. Almost the entire structure of the building and its walls are made of wood, with no roof even in some production areas. For some people, the physical appearance of such a home seem to be substandard or a slum even. But these craftsmen only need to live and work in the same location since the production of tempe requires craftsmen to always pay attention to the growth of yeast fungus.

Another non-standard physical trait of the craftsmen's houses is the space requirement. The tempeand tofu craftsmen need a much larger area of living as compared to the houses provided by developers and the government. This is because the craftsmen need their houses for living and working (informal economic activity) in the same location. Because of this, tempeand tofu craftsmen, as migrants in Jakarta, only partly own a house to live and produce. Almost every craftsman has his main home in their hometown. They see it as an embarrassment when they go to their hometown without having their own houses. As a consequence of this attitude, many craftsmen let their wives and children live in hometown.

\section{Conclussion}

The capacity constraint is one of the drivers of lowincome communities to choose to get a house in the informal housing in a neighbourhood rather than absorbing the housing market provided by the government. This also applies to low-income communities with informal economic activities. Each informal economy activity its specific network, market segments and specific market as well as unique marketing methods. All of these things can be the reasons for people with informal economic activities in determining their home needs. In certain cases, absorption is done not in a physical form (getting a real house) but in the form of occupying a land. This is the case for tempe and tahu craftsmen in Pengadegan. The houses that are available in the informal market are not their targets - a house with their needed characteristics will be too expensive in the informal market. Thus, a location on the river banks is a good option in getting the two needs of the craftsmen: affordable rental cost and the ease of disposal of soybean processing waste.

This research was funded by Direktorat Riset dan Pengabdian Masyarakat (DRPM) Universitas Indonesia in the project called PITTA.

\section{References}

1. Arifin, L. S. Ruang dan tempat untuk Berbagi Kebutuhan Rumah Bagi Wanita Pekerja Industri Pendekatan Psikologi Sosial. Surabaya: Universitas Petra. (2007)

2. Esariti, L., \& Nirwanto, A. Pemanfaatan Kredit Mikro Perumahan Bagi Masyarakat Berpenghasilan Rendah di BMT Mitra Khasanah Kota Semarang. Retrieved February 28, 2018, from TEKNIK - Vol. 29 No. 1 Tahun 2008, ISSN 0852-1697:(2008)

3. Mangeswuri, D. R. Policy on Housing Loan through Housing Loan Liquidity Facility (FLPP), from Pusat Penelitian Badan Keahlian Dewan Setjen DPR RI , Bidang Ekonomi dan Kebijakan Publik (2016)

4. Pembiayaan Perumahan, D. J. Laporan Kinerja (Lakip) Direktorat Jenderal Pembiayaan Perumahan 2016. Rakyat: (2016)

5. Primadhyta, S. $(2014,5$ 22). Pembangunan Perumahan. Retrieved 2 28, 2018, from Biro Analisa Anggaran dan Pelaksanaan APBN-SETJEN DPR-RI

6. Raharjo, N. P. (2010, February 5). Tesis: Dinamika Pemenuhan Kebutuhan Perumahan. Retrieved February 28, 2018, from Program Studi Magister Teknik Pembangunan Wilayah dan Kota Universitas Diponegoro

7. Turner, J.. Freedom to Build. London: CollierMacmillan Limited.(1972)

8. Turner, J. Housing by people: towards autonomy in building environments. London: Marion Byers.(1977) 